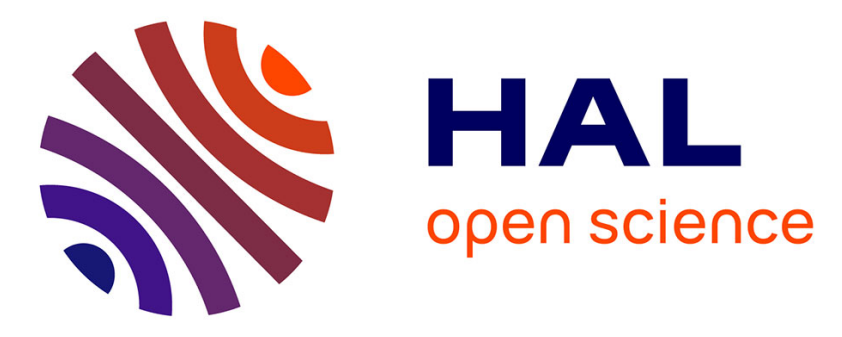

\title{
Melantheraside A-E, five original triterpenes with natural chloride or oxime group from the aerial parts of Melanthera elliptica O. Hoffm.
}

Cyrille Ngoufack Tagousop, David Ngnokam, Dominique Harakat, Laurence Voutquenne-Nazabadioko

\section{To cite this version:}

Cyrille Ngoufack Tagousop, David Ngnokam, Dominique Harakat, Laurence VoutquenneNazabadioko. Melantheraside A-E, five original triterpenes with natural chloride or oxime group from the aerial parts of Melanthera elliptica O. Hoffm.. Phytochemistry Letters, 2018, 26, pp.38-43. 10.1016/j.phytol.2018.05.007 . hal-01996059

\section{HAL Id: hal-01996059 \\ https://hal.univ-reims.fr/hal-01996059}

Submitted on 22 Sep 2021

HAL is a multi-disciplinary open access archive for the deposit and dissemination of scientific research documents, whether they are published or not. The documents may come from teaching and research institutions in France or abroad, or from public or private research centers.
L'archive ouverte pluridisciplinaire HAL, est destinée au dépôt et à la diffusion de documents scientifiques de niveau recherche, publiés ou non, émanant des établissements d'enseignement et de recherche français ou étrangers, des laboratoires publics ou privés. 
Melantheraside A-E, five original triterpenes with natural chloride or oxime group from the aerial parts of Melanthera elliptica $\mathrm{O}$. Hoffm.

Cyrille NGOUFACK TAGOUSOP ${ }^{\mathrm{a}}$, David NGNOKAM ${ }^{\mathrm{a}^{*}}$, Dominique HARAKAT ${ }^{\mathrm{b}}$ and Laurence VOUTQUENNE-NAZABADIOKO ${ }^{c}$

${ }^{a}$ Faculty of Science, Department of Chemistry, University of Dschang, P.O. Box 67. Dschang Cameroon

${ }^{\text {b} S e r v i c e ~ C o m m u n ~ d ' A n a l y s e s, ~ I n s t i t u t ~ d e ~ C h i m i e ~ M o l e ́ c u l a i r e ~ d e ~ R e i m s ~(I C M R), ~ C N R S ~}$ UMR 7312, Bat. 18 B.P.1039, 51687 Reims Cedex2, France

${ }^{\mathrm{c}}$ Groupe Isolement et Structure, Institut de Chimie Moléculaire de Reims (ICMR), CNRS UMR 7312, Bat. 18 B.P.1039, 51687 Reims Cedex2, France

*Corresponding author. E-mail.dngnokam@yahoo.fr/ngnokam@univ-dschang.org

\section{Corresponding authors:}

* Professor David Ngnokam, Laboratory of Environmental and Applied Chemistry, Department of Chemistry, Faculty of Science, University of Dschang, P.O. Box 67, Dschang, Cameroon, Tel: +237 696710 992. E-mail: dngnokam@yahoo.fr/ngnokam@univ-dschang.org 


\begin{abstract}
Five new pentacyclic triterpenoids, Melantheraside A-E (1-5) together with eleven known compounds (6-16) were isolated from the methanol extract of the aerial parts of Melanthera elliptica O. Hoffm. Their structures were established by extensive analysis of $1 \mathrm{D}-\left({ }^{1} \mathrm{H},{ }^{13} \mathrm{C}\right)$, 2D- (COSY, ROESY, HSQC and HMBC) NMR data experiments in conjunction with mass spectrometry (TOFESIMS and HR-TOFESIMS) and by comparison with data reported in the literature. The structures of the new compounds were established as: $12 \alpha$-chloro, $3 \beta, 13 \beta$ dihydroxyoleanan-28, 13-olide (1), 3-O-acetyl-12 $\alpha$-hydroxytaraxer-14-en-28-oic acid (2), 12oxime-3 $\beta$-hydroxytaraxeran-28,14-olide (3), 12-oxime-3-O-acetyl-taraxeran-28,14-olide (4) and 3-oxo-2 $\beta$-carboxyamino-12 $\alpha$-chloro,13 $\beta$-hydroxy-1-nor-oleanan-28,13-olide (5). The 3$O$-acetyl-12 $\alpha$-chloro, $13 \beta$-hydroxyoleanan-28,13-olide (6) was isolated for the first time as natural product.
\end{abstract}

Keywords: Melanthera elliptica, pentacyclic triterpenoids, Melantheraside

\title{
1. Introduction
}

The genus Melanthera (Asteraceae), contains 39 species of flowering plants native to North and South America, as well as Africa, Asia and Oceania (Parks, 1973). Many species of this genus such as M. elliptica and M. scandens are used traditionally for the treatment of various diseases (Agyare et al., 2009; Ajibesin et al 2008; Guede et al., 2010). Previous studies on plants of this genus revealed the presence of flavonoids, alkaloids, tannins, reducing sugars, diterpenes, terpenes and saponins (Omoyeni et al., 2012, Slimenstad et al., 1996). In the course of our continuing search for secondary metabolites with potentially interesting bioactivity, we investigated the EtOAc and $n-\mathrm{BuOH}$ soluble fractions from $\mathrm{MeOH}$ extract of aerial parts of Melanthera elliptica O. Hoffm.. We reported here the isolation and structure elucidation of five new pentacyclic triterpenoids with natural chloride and oxime substituent in addition to eleven known compounds.

\section{Results and discussion}

The crude $\mathrm{MeOH}$ extract of the aerial parts of Melanthera elliptica, was partition against EtOAc and $n-\mathrm{BuOH}$ by liquid-liquid partition. Purification on silica gel column chromatographies of EtOAc soluble fractions led to the isolation of five new compounds, Melantheraside A-E (1-5) and three known compounds (6-9). Similarly, purification on silica 
gel column chromatography and Sephadex LH-20 of $n$-BuOH soluble fractions gave the identification of six known compounds (10-16).

Melantheraside A (1) was obtained as a white powder which reacted positively with Liebermann-Burchard reagent. Its TOFESIMS spectrum exhibited a sodium adduct peak at $m / z, 513.3120[\mathrm{M}+\mathrm{Na}]^{+}$(calcd. for $\mathrm{C}_{30} \mathrm{H}_{47} \mathrm{O}_{3} \mathrm{ClNa}$ 513.3111). The intensity of isotopic ion at $\mathrm{m} / \mathrm{z} 515.3085[\mathrm{M}+\mathrm{Na}+2]^{+}$was about one third comparing with $[\mathrm{M}+\mathrm{Na}]^{+}$ion, which was attributed to the presence of element chlorine. These MS data and ${ }^{13} \mathrm{C}$ NMR spectrum (Table 1) corresponded to a molecular formula $\mathrm{C}_{30} \mathrm{H}_{47} \mathrm{O}_{3} \mathrm{Cl}$ for compound 1. Comparison of the ${ }^{1} \mathrm{H}$ and ${ }^{13} \mathrm{C}$ NMR data with related triterpenoids indicated that $\mathbf{1}$ was a typical oleanane-type triterpenoid with one hydroxyl group (Monte et al., 1998, Ogawa et al., 2007). The ${ }^{1} \mathrm{H}$ NMR spectrum (Table 1) of 1 exhibited seven tertiary methyl groups at $\delta_{\mathrm{H}}: 0.91(\mathrm{H}-23, \mathrm{~s}), 0.68(\mathrm{H}-$ 24, s), 0.83 (H-25, s), 1.11 (H-26, s), 1.34 (H-27, s), 0.96 (H-29, s) and 0.87 (H-30, s), an oxygenated methine at $\delta_{\mathrm{H}} 3.03(\mathrm{H}-3, d d, 11.9,4.8 \mathrm{~Hz})$, a chloro-methine at $\delta_{\mathrm{H}} 4.41(\mathrm{H}-12, d d$, $3.8,2.5 \mathrm{~Hz})$ and one methine at $\delta_{\mathrm{H}} 2.14(\mathrm{H}-18, m)$. This was confirmed by its ${ }^{13} \mathrm{C} \mathrm{NMR}$ spectrum (Table 1) on which, carbon signals of seven methyl groups were at $\delta_{\mathrm{C}}: 28.5(\mathrm{C}-23)$, 16.3 (C-24), 16.9 (C-25), 19.0 (C-26), 20.2 (C-27), 33.4 (C-29) and 24.1 (C-30) with one hydroxymethine at $\delta_{\mathrm{C}} 77.1(\mathrm{C}-3)$ and a methine at $\delta_{\mathrm{C}} 50.8(\mathrm{C}-18)$ characteristic of oleanane-type triterpenes (Mahato and Kundu, 1994). The HSQC spectrum located the carbon of the chloro-methine at $\delta_{\mathrm{C}}: 65.3(\mathrm{C}-12)$ as in compound $\mathbf{6}$, obtained by synthesis (Ogawa et al., 2007) and two natural chloro-saponin (Monte et al. 1998, Xu et al., 2010). The extensive analysis of the HSQC spectrum led us to attribute the signals at $\delta_{\mathrm{C}} 91.3$ to a quaternary $\mathrm{sp}^{3}$ hydroxylated carbon. The correlation in HMBC spectrum between the oxymethine proton signal at $\delta_{\mathrm{H}} 3.03(\mathrm{H}-3)$ and the two methyl groups at $\delta_{\mathrm{C}}: 28.5(\mathrm{C}-23)$ and 16.3 (C-24), confirme the hydroxyl group position C-3. The coupling constant of 8.5 and 6.8 $\mathrm{Hz}$ with both protons $\mathrm{H}-2$ indicated an $\alpha$-axial orientation for $\mathrm{H}-3$ and thus that hydroxyl was $\beta$-orientated. Moreover, signal of H-3 showed correlation in COSY spectrum with the proton of the hydroxyl group at $\delta_{\mathrm{H}} 4.32(\mathrm{~d}, \mathrm{~J}=5.2 \mathrm{~Hz})$ indicating that this hydroxyl group was free and not acetylated as in compound 6 (Ogawa et al., 2007). According to HMBC, the proton at $\delta_{\mathrm{H}} 2.12$ was correlated with carbons at $\delta_{\mathrm{C}} 178.4(\mathrm{C}-28), 91.3(\mathrm{C}-13), 65.3(\mathrm{C}-12), 45.7(\mathrm{C}-$ 17) and 43.0 (C-14), indicating that this proton was attributed to H-18. Comparing with a serie of oleanane-type lactone (Fu et al., 2005, Ogawa et al., 2007, Xu et al., 2010), compound 1 was established as an oleane13,28 lactone (Table 1). The chlorinated-proton at 
$\delta_{\mathrm{H}} 4.41(\mathrm{H}-12, d d, 3.8,2.5 \mathrm{~Hz})$ was correlated in the HMBC spectrum with the carbons at $\delta_{\mathrm{C}}$ 91.3 (C-13), 50.8 (C-18), 44.8 (C-9), 43.0 (C-14), and 29.4 (C-11) confirming its position at C612 as in compound 6. The small coupling constant of $\mathrm{H}-12$ with the methylene protons $\mathrm{H}-$ 11 suggested a $\beta$-equatorial position of $\mathrm{H}-12$ and an a-orientation for chlorure. This is confirmed by the ROESY correlation between $\mathrm{H}-12$ and $\mathrm{H}-11 \beta / \mathrm{H}-18$ also indicated the alpha orientation of 12-Cl. The ROESY correlations observed between H-3 and H-23/H-5; H-5 and H-9, H-27 and H-9/H-19 $(\alpha), \mathrm{H}-16(\alpha)$ and H-21 $(\alpha) / \mathrm{H}-22(\alpha), \mathrm{H}-25$ and H-26, H-18 and H12/H-30, H-30 and H-22 ( $\beta$ ) (Figure 2) provided evidence for the triterpenoid ring fusion of $\mathrm{A} / \mathrm{B}$ trans, $\mathrm{B} / \mathrm{C}$ trans, $\mathrm{C} / \mathrm{D}$ trans, $\mathrm{D} / \mathrm{E}$ cis and $13 R$ configuration. Accordingly, the structure of compound 1, melantheraside A was established as $12 \alpha$-chloro, $3 \beta, 13 \beta$-dihydroxyoleanan28,13-olide.

Compound 6, 3-O-acetyl-12 $\alpha$-chloro, $13 \beta$-hydroxyoleanan-28,13-olide, was previously described in the literature as a synthetic triterpenoid (Ogawa et al., 2007), and was identified as the 3-O-acetyl derivatives of compound 1. In the ${ }^{1} \mathrm{H}$ and ${ }^{13} \mathrm{C}$ NMR spectra, the signals of an acetyl group were observed at $\delta_{\mathrm{H}} 2.00(3 \mathrm{H}, \mathrm{s})$ and $\delta_{\mathrm{C}} 170.7$ and 21.5 (Table 1). Its position at C-3 was determined through an HMBC experiment in which the oxymethine proton signal at $\delta_{\mathrm{H}} 4.42(\mathrm{H}-3)$ showed ${ }^{3} J_{C-H}$ correlation with the carbonyl at $\delta_{\mathrm{C}} 170.7$. Compound 6, melantheraside $\mathrm{F}$, was firstly isolated here as a natural product.

Melantheraside B (2) was isolated as a white amorphous powder and also reacted positively with Liebermann-Burchard reagent. Its positive TOFESIMS exhibited a sodium adduct at $\mathrm{m} / \mathrm{z}$ $537[\mathrm{M}+\mathrm{Na}]^{+}$. Its positive HR-TOFESIMS exhibited a sodium adduct peak at $\mathrm{m} / \mathrm{z} 519.3456$ $\left[\mathrm{M}+\mathrm{Na}-\mathrm{H}_{2} \mathrm{O}\right]^{+}$(calcd. for $\mathrm{C}_{32} \mathrm{H}_{48} \mathrm{O}_{4} \mathrm{Na} 519.3450$ ) indicating the loss of an hydroxyl group. The molecular formula was also identified as $\mathrm{C}_{32} \mathrm{H}_{50} \mathrm{O}_{5}$. The ${ }^{1} \mathrm{H}$ NMR spectrum of 2 (Table 2) exhibited resonances for seven tertiary methyl groups at $\delta_{\mathrm{H}}: 0.79\left(\mathrm{H}_{3}-23, \mathrm{~s}\right), 0.81\left(\mathrm{H}_{3}-24\right.$, s), $0.89\left(\mathrm{H}_{3}-25, \mathrm{~s}\right), 0.87\left(\mathrm{H}_{3}-26, \mathrm{~s}\right), 1.02\left(\mathrm{H}_{3}-27, \mathrm{~s}\right), 0.91\left(\mathrm{H}_{3}-29, \mathrm{~s}\right)$ and $0.91(\mathrm{H}-30, \mathrm{~s}), \mathrm{a}$ methine at $\delta_{\mathrm{H}} 2.62(\mathrm{H}-18, d d, 13.4,4.6)$ and an olefinic proton at $\delta_{\mathrm{H}} 5.68(\mathrm{H}-15, d d, 8.2,3.3)$ characteristic of taraxer-14-ene triterpenes with one oxidated methyl group (Mahato and Kundu, 1994). The correlation observed in its $\mathrm{HMBC}$ spectrum between the proton at $\delta_{\mathrm{H}}$ $2.62(\mathrm{H}-18)$ and carbonyl group at $\delta_{\mathrm{C}} 179.1$ confirmed the oxidative nature of methyl C-28. In the same spectrum, correlations observed between the proton at $\delta_{\mathrm{H}} 1.02\left(\mathrm{H}_{3}-27\right)$ and the carbons at $\delta_{\mathrm{C}} 40.0(\mathrm{C}-18), 43.4(\mathrm{C}-13), 71.1(\mathrm{C}-12)$, and $157.3(\mathrm{C}-14)$ confirmed the taraxastane type skeleton of this compound. The ${ }^{13} \mathrm{C}$ NMR data combined with HSQC 
spectrum indicated the presence of trisubstituted double bond at $\delta_{\mathrm{C}} 157.3(\mathrm{C}-14)$ and 121.2 (C-15), a carbonyl group at $\delta_{\mathrm{C}} 179.1$ (C-28) and two oxymethine signals at $\delta_{\mathrm{C}} 80.2$ (C-3) and 71.1 (C-12). The position $\mathrm{C}_{14}-\mathrm{C}_{15}$ of double bond was confirmed by the HMBC correlation between the proton at $\delta_{\mathrm{H}} 5.68(\mathrm{H}-15)$ and the carbons at $\delta_{\mathrm{C}} 39.3(\mathrm{C}-8), 43.4(\mathrm{C}-13), 29.3(\mathrm{C}-$ 16) and 50.4 (C-17). The $\beta$ configuration of proton $\mathrm{H}-12$ and $\mathrm{H}-18$ were confirmed with the ROESY experiment that showed the correlations between $\mathrm{H}-12$ and $\mathrm{H}-18$ on the one hand, $\mathrm{H}-$ 18 and $\mathrm{H}_{3}-26 / 30$ on the other. In addition, the ROESY correlations between $\mathrm{H}_{3}-25 / \mathrm{H}_{3}-26 \beta$ orientated, $\mathrm{H}-3 / \mathrm{H}-5 / \mathrm{H}-9$, and $\mathrm{H}_{3}-27 / \mathrm{H}-16 \alpha$-oriented (Figure 3) provide evidence of the triterpenoid ring fusion of $\mathrm{A} / \mathrm{B}$ trans, $\mathrm{B} / \mathrm{C}$ trans, D/E cis and $13 \mathrm{~S}$ configuration (Kuroda et al., 2006). In addition to the proton and carbon resonances assigned to the portion of compound 2, we note the presence of an acetyl group $\left[\delta_{\mathrm{C}} 170.6(\mathrm{CO}), 21.5\left(\mathrm{CH}_{3}\right)\right]$ on the ${ }^{13} \mathrm{C} \mathrm{NMR}$ spectrum (Table 2). Its position was deduced on the basis of the HMBC correlation between oxymethine proton at $\delta_{\mathrm{H}} 4.38(\mathrm{H}-3)$ and the carbonyl carbon at $\delta_{\mathrm{C}} 170.6$. The configuration of the acetyl group at C-3 was assigned as $\beta$ on the basis of the interactions observed between $\mathrm{H}-3$ and $\mathrm{CH}_{3}-23 / \mathrm{CH}_{3}-25$ in the ROESY experiment. Thus, compound 2, melantheraside $\mathrm{B}$ is, 3-O-acetyl-12 $\alpha$-hydroxytaraxer-14-en-28-oic acid.

Melantheraside C (3), obtained as white powder gave the same result as the previous compounds with Liebermann-Burchard reagent and had a molecular formula $\mathrm{C}_{30} \mathrm{H}_{47} \mathrm{NO}_{4}$ deduced from a sodium adduct peak at $m / z$ 508.3410 $[\mathrm{M}+\mathrm{Na}]^{+}$(calcd. for $\mathrm{C}_{30} \mathrm{H}_{47} \mathrm{NO}_{4} \mathrm{Na}$ 508.3403) on its positive HR-TOFESIMS spectrum. The ${ }^{1} \mathrm{H}$ and ${ }^{13} \mathrm{C}$ NMR spectra (Table 2) of compound 3, exhibited signals attributed to the taraxerane triterpenoid with one oxidated methyl (Mahato and Kundu, 1994). Its ${ }^{1} \mathrm{H}$ NMR spectrum exhibited a signal at $\delta_{\mathrm{H}}: 10.33$ $(1 \mathrm{H}, s)$ attributed to a hydroxyl of oxime group in addition to the signal observed in the ${ }^{13} \mathrm{C}$ NMR spectrum at $\delta_{\mathrm{C}} 162.6$ attributed to the quaternary $\mathrm{sp}^{2}$ carbon atom of this oxime group (Nian et al., 2017). From the same ${ }^{13} \mathrm{C}$ NMR spectrum, the signal at $\delta_{\mathrm{C}} 77.1$ was attributed to C-3; this was comforted by its HMBC correlation with the methyls signals $\mathrm{H}_{3}-23$ and $\mathrm{H}_{3}-24$. This carbon C-3 was hydroxylated. In ${ }^{1} \mathrm{H}-{ }^{1} \mathrm{H}$ COSY spectrum, correlation observed between the proton $\mathrm{H}-3$ at $\delta_{\mathrm{H}} 3.00$ and that at $\delta_{\mathrm{H}} 4.32(3-\mathrm{OH})$ indicated that this hydroxyl group was not involved in any ether bond. The deshielding of carbon C-14 $\left(\delta_{\mathrm{C}} 91.1\right)$ suggested that, this carbon is linked to a hydroxy group, probably coming from hydroxylation of the olefinic carbons of the $\Delta^{14-15}$ functionality of taraxerane skeleton. The correlation observed in its HMBC spectrum between the proton at $\delta_{\mathrm{H}} 2.07(\mathrm{H}-18), 1.32\left(\mathrm{H}_{3}-27\right)$ and the oxime carbon 
atom allowed us to locate this oxime group at position $\mathrm{C}-12$. This spectrum also showed the correlation between the oxygenated carbon at $\delta 91.1$ (C-14) involved in the lactone ring and the protons H-9, H-15, H-16 and $\mathrm{H}_{3}-27$. The correlation between H-21 $(\alpha)$ and H-16 $(\alpha)$; H$22(\alpha)$ and H-16 $(\alpha) ; \mathrm{H}_{3}-27$ and H-19 $(\alpha)$, observed in ROESY spectrum indicated the cisfusion of D-E ring and consequently the $\beta$-orientation of the $\gamma$-lactone ring $(\mathrm{C}-28,14)$ (figure 4). The same ROESY experiment had confirmed the beta configuration of the proton $\mathrm{H}-18$ and the hydroxy group at $\mathrm{C}-3$. Therefore, compound $\mathbf{3}$, melantheraside $\mathrm{C}$, is 12-oxime-3 $\beta$ hydroxytaraxeran-28,14-olide.

Melantheraside D (4) was isolated as a white powder and gave a positive test with Liebermann-Burchard reagent. Its molecular formula $\mathrm{C}_{32} \mathrm{H}_{49} \mathrm{NO}_{5}$ was deduced from its positive HR-TOFESIMS spectrum, exhibiting a sodium adduct peak at $\mathrm{m} / \mathrm{z} 550.3502$ $[\mathrm{M}+\mathrm{Na}]^{+}$(calcd. for $\mathrm{C}_{32} \mathrm{H}_{49} \mathrm{NO}_{5} \mathrm{Na}$ 550.3508). A comparison with compound $3(\mathrm{~m} / \mathrm{z}$ 508.3410) suggested the presence of an additional acetyl group. The ${ }^{1} \mathrm{H}$ NMR and ${ }^{13} \mathrm{C}$ NMR (Table 2) spectra of compound $\mathbf{4}$ were almost imposable to those of compound $\mathbf{3}$, excepted the supplementary acetyl group $\left[\delta_{\mathrm{C}} 170.6(\mathrm{CO}), 21.5\left(\mathrm{CH}_{3}\right)\right]$ and the chemical shift of protons $\mathrm{H}-3, \mathrm{H}_{3}-23$ and $\mathrm{H}_{3}-24$ (Table 2$)$. The deshielding signals of $\mathrm{H}-3$ at $\delta_{\mathrm{H}} 4.43(\Delta+1.43 \mathrm{ppm})$ and C-3 $\delta_{\mathrm{c}} 80.0(\Delta+2.9 \mathrm{ppm})$ suggested the position of esterification. This was readily confirmed by the HMBC experiment in which the oxymethine proton at $\delta_{\mathrm{H}} 4.43(\mathrm{H}-3 \alpha)$ showed the correlation with the carbonyl at $\delta_{\mathrm{C}} 170.6$. From the above information, compound 4, melantheraside $\mathrm{D}$, is 12-oxime-3-O-acetyltaraxeran-28,14-olide.

Melantheraside E (5) obtained as white powder gave the same result as compounds (1-4) with Liebermann-Burchard reagent. The positive TOFESIMS spectrum gave a sodium adduct peak at $m / z$ : $556.2816[\mathrm{M}+\mathrm{Na}]^{+}$(calcd. for $\mathrm{C}_{30} \mathrm{H}_{44} \mathrm{NO}_{5} \mathrm{ClNa} 556.2806$ ), indicating a chlorinated triterpenoid with a molecular formula of $\mathrm{C}_{30} \mathrm{H}_{44} \mathrm{NO}_{5} \mathrm{Cl}$. The ${ }^{1} \mathrm{H}$ and ${ }^{13} \mathrm{C} \mathrm{NMR}$ spectra (Table 1) of compound $\mathbf{5}$ were very similar to those of compound $\mathbf{1}$ in the high field, except for signals of ring A. This observation confirmed the oleanane-type triterpene of compound 5 (Mahato and Kundu, 1994). Signals at $\delta_{\mathrm{H}} 12.20$ and 5.56 on its ${ }^{1} \mathrm{H}$ NMR spectrum (Table 1) were attributed to acid and amide groups while those at $\delta_{\mathrm{H}} 4.42$ was attributed to chloromethine as in compound 1. A supplementary signal at $\delta_{\mathrm{H}} 4.80(\mathrm{~d}, J=1.7$ $\mathrm{Hz}$ ), showed cross-peak correlation on ${ }^{1} \mathrm{H}-{ }^{1} \mathrm{H}$ COSY spectrum with the amide proton at $\delta_{\mathrm{H}}$ 5.56 suggesting an aminomethine for this proton. Its ${ }^{13} \mathrm{C} N M R$ spectrum showed signals at three carbonyl groups at $\delta_{\mathrm{C}} 203.5,178.3$ and 156.2 assigned to the carbonyl of ketone, 
lactone and amide group, respectively. This ${ }^{13} \mathrm{C}$ NMR also showed the signals of an oxygenated quaternary carbon at $\delta_{\mathrm{C}} 91.4(\mathrm{C}-13)$, and a chloromethine carbon at $\delta_{\mathrm{C}} 64.7(\mathrm{C}-$ 12), as in compounds 1 and 6 (Table 1). In addition, signal at $\delta_{\mathrm{C}} 64.6$ was attributed to the aminomethine carbon by its correlation in the HSQC spectrum with the proton at $\delta_{\mathrm{H}} 4.80$. The HMBC correlation between the proton at $\delta_{\mathrm{H}} 4.80$ and the carbonyl at $\delta_{\mathrm{C}} 156.2$, confirmed the existence of the carboxyamino group in the structure of compound 5. In the HMBC spectrum, the correlation between the methyl protons at $\delta_{\mathrm{H}} 1.09\left(\mathrm{H}_{3}-23\right)$ and $0.96\left(\mathrm{H}_{3}-24\right)$ with the carbon at $\delta_{\mathrm{C}} 203.5$ indicated the position C-3 for the ketone. The extensive analysis of HMBC correlations between proton at $\delta_{\mathrm{H}} 4.80(\mathrm{H}-2)$ and carbons $\mathrm{C}-3\left(\delta_{\mathrm{C}} 203.5\right), \mathrm{C}-4\left(\delta_{\mathrm{C}} 47.3\right), \mathrm{C}-5$ $\left(\delta_{\mathrm{C}} 44.7\right), \mathrm{C}-9\left(\delta_{\mathrm{C}} 33.6\right)$, and C-10 $\left(\delta_{\mathrm{C}} 40.3\right)$ indicated the 3-oxo-cyclopentanic type of ring $\mathrm{A}$ (He et al., 2009). Thus compound $\mathbf{5}$ is a 1-noroleanane type skeleton and the carboxamino group was attached to position $\mathrm{C}$-2. The $\beta$-orientation of the carboxamino group was deduced from the ROESY correlations between $\mathrm{H}-2 / \mathrm{H}-9, \mathrm{H}-5 / \mathrm{H}-9, \mathrm{H}_{3}-27 / \mathrm{H}-9 \alpha$-oriented. The relative $13 \beta$-configuration of hydroxy group, and $\beta$-configuration of protons $\mathrm{H}-12$ and $\mathrm{H}-18$ were determined using the ROESY experiment as in compounds 1-4. Thus compound 5, melantheraside $\mathrm{E}, \quad$ is 3 -oxo- $2 \beta$-carboxyamino-12 $\alpha$-chloro,13 $\beta$-hydroxy-1-noroleanan28,13olide.

The known compounds were identified by comparison of their spectroscopic data with literature values as: oleanolic acid (7) (Mahato and Kundu, 1994), auriantiamide (8) (Avijit and Rita, 1981), auranamide (9) (Catalan et al., 2003), Didymin (10) (Gattuso et al., 2007), 3-O- $\beta$-D-glucuronopyranosyl-oleanolic acid (11) (Vidal-Ollivier et al., 1989), oleanolic acid 28-O- $\beta$-D-glucopyranosyl ester (12) (Min et al., 2012), 3- $O$ - $\beta$-D-glucuronopyranosyl oleanolic acid 28-O- $\beta$-D-glucopyranosyl ester (13) (Vidal-Ollivier et al., 1989), 3-O- $\beta$-Dglucopyranosyl-( $1 \rightarrow 2)-\beta$-D-glucuronopyranosyl oleanolic acid (14) (Paphassarang et al., 1989), 3- $O$ - $\beta$-D-glucopyranosyl-( $(\rightarrow 2)-\beta$-D-glucuronopyranosyl oleanolic acid $28-O-\beta$-Dglucopyranosyl ester (15) (Lee et al., 2013) and mannitol (16) (Kim et al., 2008).

In conclusion, compounds 11 and $\mathbf{1 3}$ were previously isolated from Melanthera scandens (Penders and Delaude, 1994). All saponins are oleanolic acid derivatives. Compounds 1, 5 and 6 with a chloride are original and rare in the nature, similar compounds were identified in the kiwifruit Actinidia chinensis (Xu et al., 2010). To our knowledge, compounds $\mathbf{3}$ and $\mathbf{4}$ are the first triterpenoid with an oxime group at C-12 obtained as natural product. Only 
triterpenoids with an oxime group at C-15 were recently identified in Cimicifuga frigida (Nian et al., 2017).

\section{Experimental}

\subsection{General experimental procedures}

Melting points were recorded with a Schorpp Gerätetechnik apparatus. ${ }^{1} \mathrm{H}$ and ${ }^{13} \mathrm{C}$ NMR spectra were recorded on a Bruker Avance III 600 spectrometer equipped with a cryoprobe $\left({ }^{1} \mathrm{H}\right.$ at $600 \mathrm{MHz}$ and ${ }^{13} \mathrm{C}$ at $\left.150 \mathrm{MHz}\right)$. 2D NMR experiments were recorded by means of standard Bruker microprograms (Xwin-NMR version 2.1 software TopSpin 3.2). Chemical shifts $(\delta)$ are reported in parts per million (ppm) using the residual solvent signals as secondary reference relatively to TMS $(\delta=0)$, while the coupling constants ( $J$ values) are given in Hertz $(\mathrm{Hz})$. TOF-ESIMS and HR-TOFESIMS spectra were recorded using a Micromass Q-TOF micro instrument (Manchester, UK) equipped with an electrospray source. The samples were introduced by direct infusion in a solution of $\mathrm{MeOH}$ at a rate of 5 $\mathrm{mL} \min ^{-1}$. Column chromatography was run on Merck silica gel 60 (70-230 mesh) and gel permeation on Sephadex LH-20 while TLC was carried out on silica gel GF254 pre-coated plates with detection accomplished by spraying with $50 \% \mathrm{H}_{2} \mathrm{SO}_{4}$ followed by heating at 100 ${ }^{\circ} \mathrm{C}$, or by visual inspection under UV lamp at 254 and $365 \mathrm{~nm}$.

\subsection{Plant material}

The aerial parts of Melanthera elliptica were collected at FOTO Village (Menoua Division, Western region of Cameroon) in January 2014. Authentication was done by Mr. Fulbert Tadjouteu, a Botanist of the Cameroon National Herbarium, Yaoundé, where a voucher specimen $\left(\mathrm{N}^{\circ} 8002 / \mathrm{HNC}\right)$ has been deposited.

\subsection{Extraction and isolation}

The air-dried plant material $(4 \mathrm{~kg})$ was powdered and extracted at room temperature with methanol ( 3 x $20 \mathrm{~L}, 72 \mathrm{~h})$. The solvent was evaporated under reduced pressure, leaving an extract $(220 \mathrm{~g})$. Part of this extract $(210 \mathrm{~g})$ was suspended in water $(300 \mathrm{~mL})$ and successively extracted with equal volumes $(500 \mathrm{~mL})$ of ethyl acetate (EtOAc) and $n$-BuOH yielding respectively $65 \mathrm{~g}$ and $30 \mathrm{~g}$ fractions after evaporation to dryness. 
A part of the $n-\mathrm{BuOH}$ fraction (25 g) was subjected to silica gel column chromatography using EtOAc-MeOH (10:0 $\rightarrow 4: 6)$ gradient as eluent. 47 fractions of $250 \mathrm{~mL}$ each were collected and combined on the basis of their TLC profiles to give 5 fractions: A (1-7), B (812), C (13-15), D (16-47) and E (24-47). Fraction A (3.5 g) was purified on silica gel column chromatography eluted with $n$-hexane-EtOAc (2:8) to give compound 12 (35 mg). Fraction B ( $3 \mathrm{~g}$ ) was also purified on silica gel column chromatography eluted with EtOAc to give compound 11 (75 mg). Fraction C (5 g) mainly yielded compounds 13 (30 mg), 14 (30 mg) and 10 (10 mg) after multiple chromatographic steps over sephadex LH-20 using $\mathrm{MeOH}$ as eluents and silica gel using EtOAc- $\mathrm{MeOH}-\mathrm{H}_{2} \mathrm{O}$ (95:5:2) and (9:0,5:0,5) as eluents. Fraction D (6 g) submitted on column chromatography separation over silica gel eluted with EtOAc$\mathrm{MeOH}(85: 15)$ yielded three sub-fractions $\left(\mathrm{D}_{1}-\mathrm{D}_{3}\right)$. Compound 15 (30 mg) was obtain to fraction $\mathrm{D}_{2}$ after multiple chromatography separation over silica gel using EtOAc-MeOH$\mathrm{H}_{2} \mathrm{O}(8: 1: 1)$ and (8:2:1) as eluents while compound 16 (50 mg) was obtain after purification of fraction $\mathrm{E}$ on silica gel column chromatography using EtOAc- $\mathrm{MeOH}-\mathrm{H}_{2} \mathrm{O}(8: 2: 1)$.

One part of EtOAc fraction (60 g) was subjected to silica gel column chromatography using $n$-Hexane-EtOAc $(100: 0 \rightarrow 0: 100)$ gradient as eluent. 60 fractions of $250 \mathrm{~mL}$ each were collected and combined on the basis of their TLC profiles to give 7 fractions: F (1-7), G (815), H (16-25), I (26-35), J (36-45), K (46-51) and L (52-60). Fraction G (5g) was purified on column chromatography using $n$-Hexane- EtOAc (95:5) as eluent to give compounds 6 (45 $\mathrm{mg}$ ) and 2 (15 mg). Compound 1 (30 mg) was obtained after purification of fraction $\mathrm{H} \mathrm{(4} \mathrm{g)}$ on silica gel column chromatography using the same eluent at the same polarity available to purify the fraction G. Fraction I ( $8 \mathrm{~g}$ ) was purified on silica gel column chromatography with $n$-hexane-AcOEt (90-10) to give 2 sub-fractions $\left(\mathrm{I}_{1}-\mathrm{I}_{2}\right)$. Sub-fraction $\mathrm{I}_{1}$ (3 g) yielded compound 7 (60 mg) after filtration. Sub-fraction I2 (4 g) was purified on a silica gel column chromatography using n-Hexane-EtOAc (85:15) as eluent. The $10 \mathrm{~mL}$ sub-fractions were collected and pooled on the base of their TLC profiles in two sub-fractions I2-1 (1.2 g) and I2-2 (0.8 g). The sub-fraction I2-1 was recrystallized in ethyl acetate to give compound 4 (25 $\mathrm{mg}$ ). The subfraction I2-2 was purified over silica gel column chromatography using $n$ Hexane-EtOAc (80:20) as eluent to give compound 3 (15 mg). Compound 5 (20 mg) was also obtained after purification of fraction $\mathrm{J}(4 \mathrm{~g})$ by column chromatography on silica gel eluted with $n$-Hexane-EtOAc (75:25). The purification of fraction $\mathrm{K}(4 \mathrm{~g})$ on silica gel column chromatography using $n$-Hexane-EtOAc (60: 40) give compounds 8 (20 mg) and 9 (25 mg). 
3.4. New compounds information

Melantheraside A (1): white powder; m.p. $=254.6{ }^{\circ} \mathrm{C}$; $[\alpha]_{\mathrm{D}}{ }^{20}+59.3\left(\mathrm{CHCl}_{3} c 0.55\right)$; for ${ }^{1} \mathrm{H}$ and ${ }^{13} \mathrm{C}-\mathrm{NMR}$ data, see Table 1; TOFESIMS (positive ion mode) $\mathrm{m} / z: 513.3120[\mathrm{M}+\mathrm{Na}]^{+}$ (calcd. for $\mathrm{C}_{30} \mathrm{H}_{47} \mathrm{O}_{3} \mathrm{ClNa}$ 513.3120), $515.3085[\mathrm{M}+\mathrm{Na}+2]^{+}$.

Melantheraside B (2): white amorphous powder; $[\alpha]_{\mathrm{D}}{ }^{20}+4.3\left(\mathrm{CHCl}_{3} c 0.12\right)$; for ${ }^{1} \mathrm{H}$ and ${ }^{13} \mathrm{C}$ NMR data, see Table 2; HR-ESIMS (positive ion mode) at $m / z, 519.3450\left[\mathrm{M}+\mathrm{Na}-\mathrm{H}_{2} \mathrm{O}\right]^{+}$ (calcd. for $\mathrm{C}_{32} \mathrm{H}_{48} \mathrm{O}_{4} \mathrm{Na} 519.3450$ ).

Melantheraside C (3): white powder; m.p. $=257.4{ }^{\circ} \mathrm{C} ;[\alpha]_{\mathrm{D}}{ }^{20}+38.9\left(\mathrm{CHCl}_{3} c 0.18\right) ;{ }^{1} \mathrm{H}$ and ${ }^{13} \mathrm{C}-\mathrm{NMR}$ data, see Table 2; HR-TOFESIMS (positive ion mode) $\mathrm{m} / \mathrm{z}: 508.3410[\mathrm{M}+\mathrm{Na}]^{+}$ (calcd. for $\mathrm{C}_{30} \mathrm{H}_{47} \mathrm{NO}_{4} \mathrm{Na} 508.3403$ ).

Melantheraside D (4): white powder; m.p. $=249.5{ }^{\circ} \mathrm{C} ;[\alpha]_{\mathrm{D}}{ }^{20}+79.2\left(\mathrm{CHCl}_{3} c 0.36\right) ;{ }^{1} \mathrm{H}$ and ${ }^{13} \mathrm{C}-\mathrm{NMR}$ data, see Table 2; HR-TOFESIMS (positive ion mode) $\mathrm{m} / \mathrm{z}: 550.3502[\mathrm{M}+\mathrm{Na}]^{+}$ (calcd. for $\mathrm{C}_{32} \mathrm{H}_{49} \mathrm{NO}_{5} \mathrm{Na} 508.3503$ ).

Melantheraside E (5): white powder; m.p. $=251.2{ }^{\circ} \mathrm{C} ;[\alpha]_{\mathrm{D}}{ }^{20}-6.0\left(\mathrm{CHCl}_{3} c 0.12\right) ;{ }^{1} \mathrm{H}$ and ${ }^{13} \mathrm{C}-\mathrm{NMR}$ data, see Table 1; TOFESIMS (positive ion mode) $\mathrm{m} / \mathrm{z}: 556.2816[\mathrm{M}+\mathrm{Na}]^{+}$(calcd. for $\mathrm{C}_{30} \mathrm{H}_{44} \mathrm{NO}_{5} \mathrm{ClNa}, 556.2806$ ).

Melantheraside F (6): white powder; m.p. $=247.6{ }^{\circ} \mathrm{C} ;[\alpha]_{\mathrm{D}}{ }^{20}+54.9\left(\mathrm{CHCl}_{3} c 0.92\right) ;{ }^{1} \mathrm{H}$ and ${ }^{13} \mathrm{C}-\mathrm{NMR}$ data, see Table 1; TOFESIMS (positive ion mode) $\mathrm{m} / \mathrm{z}: 555.3210[\mathrm{M}+\mathrm{Na}]^{+}$(calcd. for $\left.\mathrm{C}_{32} \mathrm{H}_{49} \mathrm{NO}_{4} \mathrm{ClNa}, 555.3217\right)$.

\section{Acknowledgments}

The authors are grateful to the University of Dschang for financing some consumables used in this work, to Mr. WAMO TAKAFO for it contribution in the collect of vegetal material, to the "Service Commun d'Analyses" and "Groupe Isolement et Structure", to the "Institut de Chimie Moléculaire de Reims" for the spectroscopic and spectrometric analysis on the ESIMS et NMR equipement of the PlAnet Platform. The EU-programme FEDER to the PlAneT CPER project is gratefully acknowledged.

\section{References}

Agrawal, P. K., 1992. NMR spectroscopy in structural elucidation of oligosaccharides and glycosides. Phytochemistry 31, 3307-3330. 
Agyare, C., Asase, A., Lechtenberg, M., Niehues, M., Deters, A., Hensi, A., 2009. An ethnopharmacological survey and in vitro confirmation of ethnopharmacological use of medicinal plants used for wound healing in Gosomtwi-Atwima-Kwanwoma area. Ghana. J. Ethnopharmacol. 125, 393-403.

Ajibesin, K. K., Ekpo, B. A., Bala, D. N., Essien, E. E., Adesanya, S. A., 2008. Ethnobotanical survey of Akwa Ibom State of Nigeria. J. Ethnopharmacol. 115, 387408.

Avijit, B., Rita, R., 1981. Aurantiamides: a new class of modified dipeptides from Piper aurantiacum. Phytochemistry, 20, 2217-2220.

Catalan C. A. N., Heluani, C. S., Kotowicz, C., Gedris, T. E., Herz, W., 2003. A linear sesterterpene, two squalene derivatives and two peptide derivatives from Croton hieronymi. Phytochemistry 64, 625-629.

Fu, L., Zhang, S., Li, N., Wang, J., Zhao, M., Sakai, J., Hasegawa, T., Mitsui, T., Kataoka, T., Oka S., Kiuchi, M., Hirose K., Ando M., 2005. Three New Triterpenes from Nerium oleander and Biological Activity of the Isolated Compounds J. Nat. Prod. 68, 198-206.

Gattuso, G., Barreca, D., Gargiulli, C., Leuzzi, U., Caristi, C., 2007. Flavonoid Composition of Citrus Juices. Molecules 12, 1641-1673.

Guede, N. Z., N'guessan, K., Dibie, T. E., Grellier, P., 2010. Ethnopharmacological study of plants used to treat malaria in traditional medicine by Bete populations of Issia (Cote d'voire). J. Pharmaceut. Sci. Res. 2, 216-227.

He, X.-F., Wang, X.-N., Yin, S., Dong, L., Yue, J.-M., 2009. Ring A Modified Novel Triterpenoids from Dysoxylum hainanense. Eur J Org Chem 4818-4824.

Kim, Y-S., Lee, I-K., Seok, S-J. Yun, B-S., 2008. Chemical Constituents of the Fruiting Bodies of Clitocybe nebularis and Their Antifungal Activity. Mycobiology 36, 110113.

Kuroda, M., Aoshima, T., Haraguchi, M., Young, M. C. M., Sakagami, H., Mimaki, Y., 2006. Oleanane and Taraxerane Glycosides from the Roots of Gomphrena macrocephala J. Nat. Prod. 69, 1606-1610.

Lee, D.Y., Kim, J. K., Shrestha, S., Seo, K. H., Lee, Y. H., Noh, H. J., Kim, G. S., Kim, Y. B., Kim, S. Y., Baek, N. I., 2013. Quality Evaluation of Panax ginseng Roots 
Using a Rapid Resolution LC-QTOF/MS-Based Metabolomics Approach. Molecules 18, 14849-14861.

Mahato, S. B., kundu, A. P., 1994. ${ }^{13} \mathrm{C}$ NMR spectra of pentacyclic triterpenoids- a compilation and some salient features. Phymchemistry 37, 1517-1575.

Min, Y., Xiangyun, W., Ming, W., Yu, C., Yunfa, D., Youyi, Z., Xu, F., 2012. A new triterpenoid saponin and other saponins from Salicornia europaea. Chem. Nat. Compd. 48, 258-261.

Monte, F. J. Q., J.P., Kintzinger Braz-Filho, R., 1998. Total Assignment of ${ }^{1} \mathrm{H}$ and ${ }^{13} \mathrm{C}$

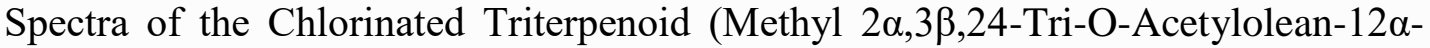
Chloro-28,13 $\beta$-Olide) by NMR Spectroscopy. Magnetic Resonnance in Chemistry, 36, 381-384.

Nian, Y., Yan, H., Li, Xi-N., Zhou, L., Qiu, M-H., 2017. Cimifrigines A-G, cytotoxic triterpenes with an oxime group from the flowers of Cimicifuga frigida. RSC Advances, 7, 38557-38564

Ogawa, S., Hosoi, K., Ikeda, N., Makino, M., Fujimoto, Y., lida, T., 2007. Oxyfunctionalization Products of Terpenoids with Dimethyldioxirane and Their Biological Activity. Chem. Pharm. Bull. 55, 247-250.

Omoyeni, O. A., Aterigbade, E., Akinyeye, R. O., Olowu, R. A., 2012. Phytochemical screening, nutritional/anti-nutritional and amino acid compositions of nigeria Melanthera scandens. Sci. Rev. Chem. Commun 2, 20-30.

Paphassarang, S., Raynaud, J., Lussignol, M., 1989. Triterpenoid saponins from Polysczas scutellarza. J. Nat. Prod. 52, 239-242.

Parks, J. C., 1973. A revision of North American and Caribbean Melanthera (Compositae). Rhodora 75, 169-210.

Penders, A., Delaude C., 1994. Triterpenoid saponins from Melanthera scandens Phytochemistry, 37, 821-825

Slimestad, R, Marston, A, Mavi, S, Hostettmann, K. 1996. Larvicidal Constituents of Melantheria albinervia Planta Medica 61(6):562-563

Vidal-Ollivier, E., Balansard, G., Faure, R., Babadjamian, A., 1989. Revised structures of triterpenoid saponins from the flowers of Calendula officinalis. J. Nat. Prod. 52, 1156-1159. 
Xu, Y-X., Xiang, Z-B., Jin, Y-S., Shen, Y., Chen, H-S., 2010. Two new triterpenoids from the roots of Actinidia chinensis. Fitoterapia, 81, 920-924

Zheng, Q., Li, W., Han, L., Koike, K., 2007. Pancreatic lipase-inhibiting triterpenoid saponins from Gypsophila oldhamiana. Chem. Pharm. Bull. 55, 646-650. 

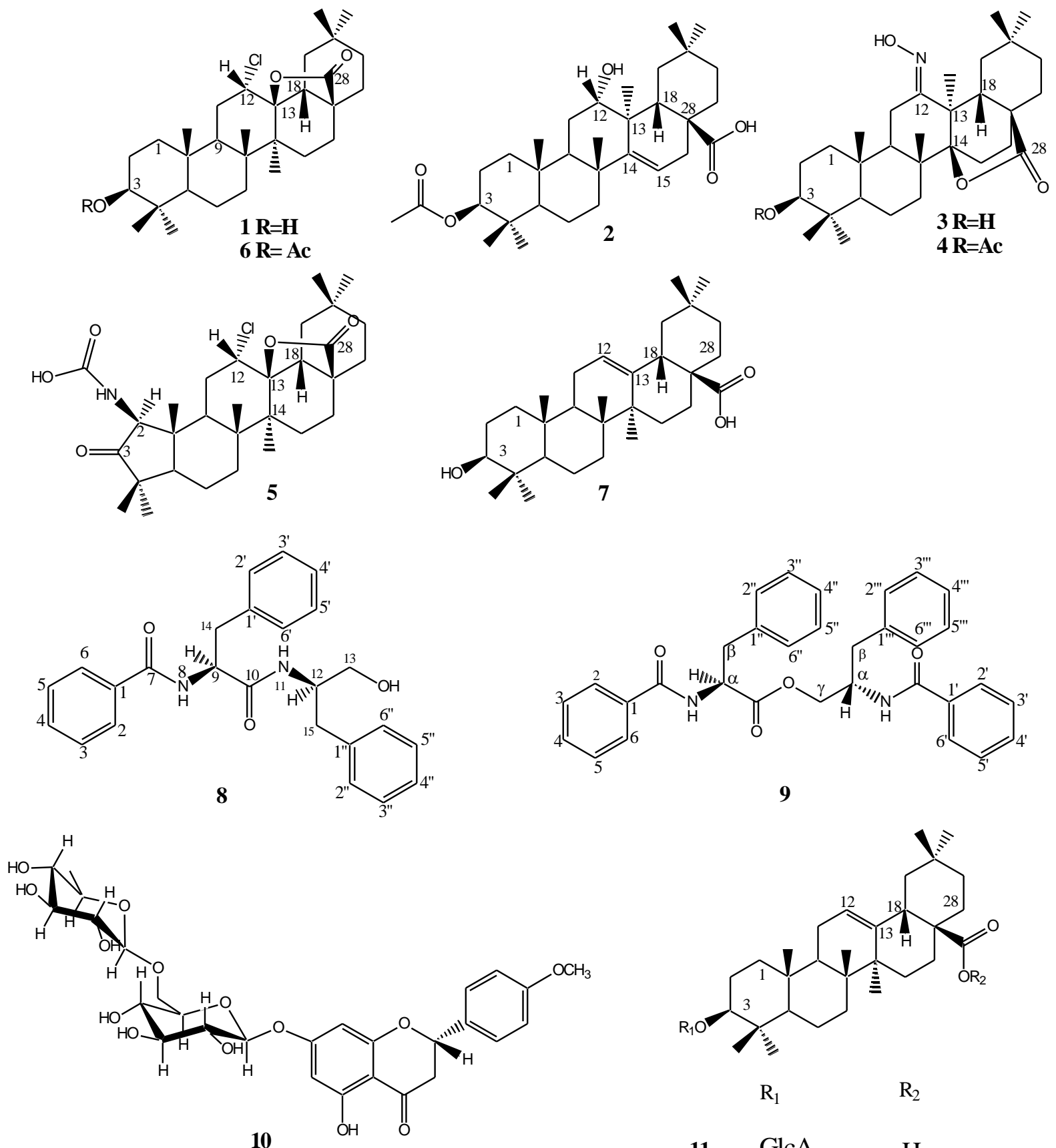

11 GlcA H

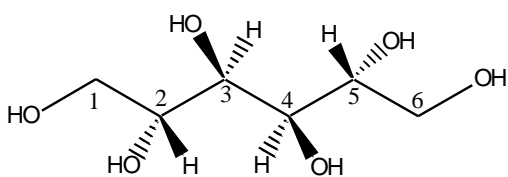

$12 \mathrm{H}$ Glc

13 GlcA Glc

14 GlcÁ-Glc H

$15 \quad \mathrm{GlcA}^{2}-\mathrm{Glc} \quad \mathrm{Glc}$

16

GlcA : $\beta$-D-glucuronopyranosyl Glc: $\beta$-D-glucopyranosyl

Fig.1 Structures of compounds 1-16 isolated from EtOAc and $n-\mathrm{BuOH}$ soluble extract of Melanthera elliptica. 


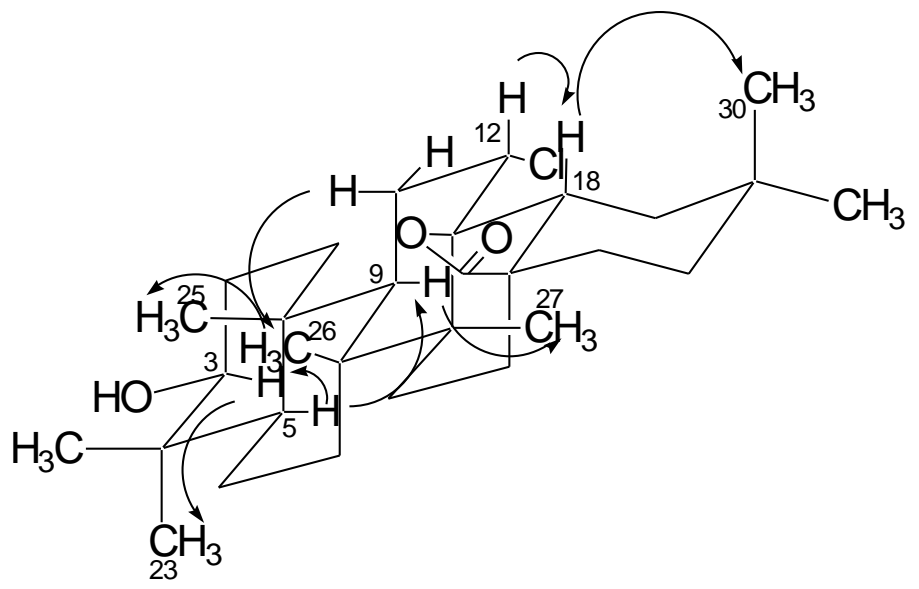

Fig.2 Key ROE correlations of compound 1

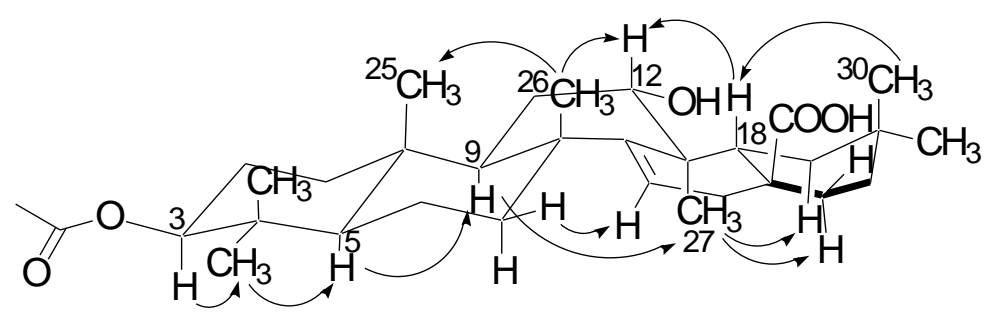

Fig.3 Key ROE correlations of compound 2

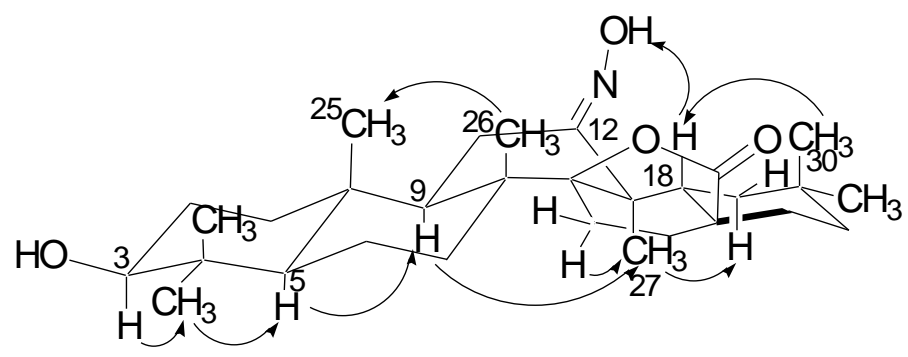

Fig.4 Key ROE correlations of compound 3 


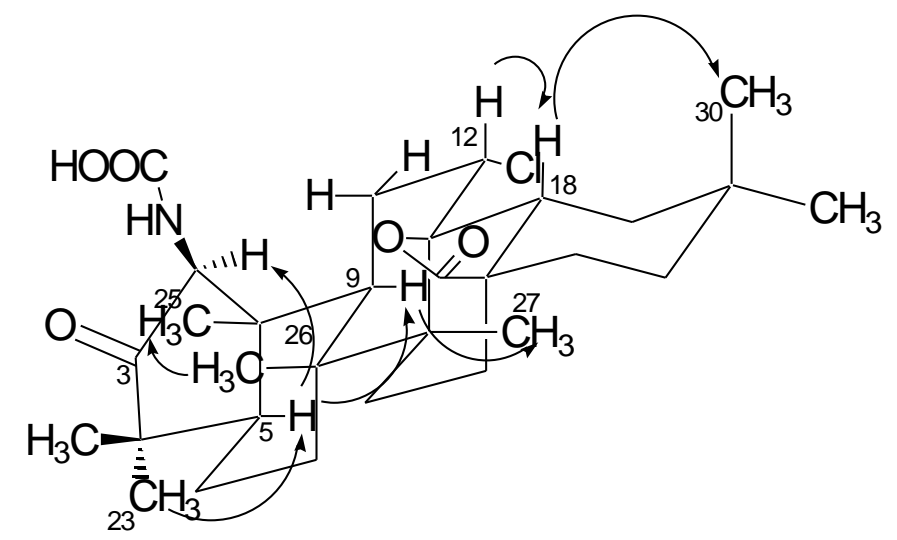

Fig.5 Key ROE correlations of compound 5 
Table 1: ${ }^{1} \mathrm{H}$ RMN $(600 \mathrm{MHz})$ and ${ }^{13} \mathrm{C}$ NMR $(150 \mathrm{MHz})$ data of compounds $(\mathbf{1 , 5}, \mathbf{6})$ in DMSO- $d_{6}$

\begin{tabular}{|c|c|c|c|c|c|c|}
\hline $\mathrm{N}^{\circ}$ & 1 & & 5 & & 6 & \\
\hline & $\delta_{\mathrm{H}}, \mathrm{m}(\mathrm{J} \mathrm{Hz})$ & $\delta_{\mathrm{C}}$ & $\delta_{\mathrm{H}}, \mathrm{m}(\mathrm{J} \mathrm{Hz})$ & $\delta_{\mathrm{C}}$ & $\delta_{\mathrm{H}}, \mathrm{m}(\mathrm{J} \mathrm{Hz})$ & $\delta_{\mathrm{C}}$ \\
\hline $1 \alpha$ & $1.62 \mathrm{dt}(12.9,3.7)$ & 38.7 & - & - & $1.68 \mathrm{~m}$ & 38.2 \\
\hline$\beta$ & $0.90 \mathrm{~m}$ & & & & $0.99 \operatorname{td}(13.2,3.9)$ & \\
\hline $2 \alpha$ & $1.49 \mathrm{~m}$ & 27.4 & $4.80 \mathrm{~d}(1.7)$ & 64.6 & $1.57 \mathrm{td}(13.1,3.1)$ & 23.6 \\
\hline$\beta$ & $1.49 \mathrm{~m}$ & & & & $1.62 \mathrm{dd}(12.4,2.6)$ & \\
\hline 3 & 3.03 ddd $(8.5,6.8,5.2)$ & 77.1 & - & 203.5 & $4.42 \mathrm{dd}(11.9,4.8)$ & 80.2 \\
\hline 4 & - & 39.0 & - & 47.3 & - $\quad$ - n & 37.8 \\
\hline 5 & $0.74 \mathrm{dd}(11.9,1.8)$ & 55.2 & $1.97 \mathrm{dd}(11.7,2.7)$ & 44.7 & $0.93 \mathrm{dd}(12.0,1.8)$ & 54.8 \\
\hline $6 \alpha$ & $1.37 \mathrm{~m}$ & 17.8 & $1.54 \mathrm{~m}$ & 18.6 & $1.43 \mathrm{~m}$ & 17.6 \\
\hline$\beta$ & $1.47 \mathrm{~m}$ & & $1.45 \mathrm{~m}$ & & $1.40 \mathrm{~m}$ & \\
\hline $7 \alpha$ & $1.54 \operatorname{td}(12.7,3.2)$ & 34.4 & $1.27 \mathrm{~m}$ & 33.4 & $1.57 \operatorname{td}(12.8,3.1)$ & 34.2 \\
\hline$\beta$ & $1.24 \mathrm{dt}(12.7,3.2)$ & & $1.52 \mathrm{~m}$ & & $1.24 \mathrm{dt}(12.8,3.1)$ & \\
\hline 8 & - & 42.4 & - & 42.1 & - & 42.4 \\
\hline 9 & $1.65 \mathrm{dd}(12.5,2.2)$ & 44.8 & $2.72 \mathrm{dd}(12.6,1.5)$ & 33.6 & $1.71 \mathrm{~d}(13.1)$ & 44.7 \\
\hline 10 & - & 36.5 & - & 40.3 & - & 36.4 \\
\hline $11 \alpha$ & 1.68 ddd $(14.8,12.5$, & 29.4 & $1.71 \mathrm{dt}(14.7,1.5)$ & 29.4 & $1.68 \mathrm{~m}$ & 29.4 \\
\hline$\beta$ & & & $2.14 \mathrm{~m}$ & & $2.12 \mathrm{~m}$ & \\
\hline & $2.10 \mathrm{dt}(14.8,2.5)$ & & & & & \\
\hline $12 \beta$ & $4.41 \mathrm{dd}(3.8,2.5)$ & 65.3 & $4.42 \mathrm{t}(2.9)$ & 64.7 & 4.41 brs & 65.2 \\
\hline 13 & - & 91.2 & - & 91.4 & - & 91.3 \\
\hline 14 & - & 43.0 & - & 43.3 & - & 43.0 \\
\hline $15 \alpha$ & $1.17 \mathrm{~m}$ & 28.9 & $1.78 \mathrm{dt}(13.5,6.0)$ & 28.8 & $1.18 \mathrm{~m}$ & 28.9 \\
\hline$\beta$ & $1.77 \operatorname{td}(13.3,6.1)$ & & $1.23 \mathrm{~m}$ & & $1.76 \operatorname{td}(13.7,5.8)$ & \\
\hline $16 \alpha$ & $1.15 \mathrm{~m}$ & 21.2 & $1.17 \mathrm{~m}$ & 21.2 & $1.13 \mathrm{dd}(13.5,5.8)$ & 21.1 \\
\hline$\beta$ & $2.21 \mathrm{td}(13.3,5.7)$ & & $2.23 \operatorname{td}(13.4,5.7)$ & & $2.21 \mathrm{td}(13.5,5.8)$ & \\
\hline 17 & - & 45.1 & - & 45.1 & - & 45.1 \\
\hline $18 \beta$ & $2.14 \mathrm{dd}(12.6,3.9)$ & 50.8 & $2.15 \mathrm{dd}(12.7,3.9)$ & 50.9 & $2.12 \mathrm{~m}$ & 50.8 \\
\hline $19 \alpha$ & $2.01 \mathrm{~m}$ & 39.6 & $2.08 \mathrm{t}(12.7)$ & 39.4 & $2.05 \mathrm{~m}$ & 39.4 \\
\hline$\beta$ & $2.05 \mathrm{t}(12.6)$ & & $2.05 \mathrm{~m}$ & & $2.01 \mathrm{t}(12.5)$ & \\
\hline 20 & - & 32.0 & - & 32.0 & - & 32.0 \\
\hline $21 \alpha$ & $1.19 \mathrm{~m}$ & 33.8 & $1.38 \mathrm{~d}(13.4,5.4)$ & 33.8 & $1.19 \mathrm{~m}$ & 33.8 \\
\hline$\beta$ & $1.37 \mathrm{~m}$ & & $1.18 \mathrm{~m}$ & & $1.37 \mathrm{~m}$ & \\
\hline $22 \alpha$ & $1.48 \mathrm{~m}$ & 27.6 & $1.49 \mathrm{~m}$ & 27.6 & $1.42 \mathrm{~m}$ & 27.5 \\
\hline$\beta$ & $1.53 \operatorname{td}(13.7,3.8)$ & & $1.52 \mathrm{~m}$ & & $1.50 \operatorname{td}(13.5,3.8)$ & \\
\hline 23 & $0.91 \mathrm{~s}$ & 28.5 & $1.09 \mathrm{~s}$ & 26.7 & $0.82 \mathrm{~s}$ & 28.0 \\
\hline 24 & $0.68 \mathrm{~s}$ & 16.3 & $0.96 \mathrm{~s}$ & 22.5 & $0.81 \mathrm{~s}$ & 16.8 \\
\hline 25 & $0.83 \mathrm{~s}$ & 16.9 & $0.81 \mathrm{~s}$ & 15.3 & $0.87 \mathrm{~s}$ & 16.9 \\
\hline 26 & $1.11 \mathrm{~s}$ & 19.0 & $1.17 \mathrm{~s}$ & 18.9 & $1.11 \mathrm{~s}$ & 19.0 \\
\hline 27 & $1.34 \mathrm{~s}$ & 20.2 & $1.38 \mathrm{~s}$ & 19.9 & $1.35 \mathrm{~s}$ & 20.2 \\
\hline 28 & - & 178.3 & - & 178.3 & - & 178.4 \\
\hline 29 & $0.96 \mathrm{~s}$ & 33.4 & $0.97 \mathrm{~s}$ & 33.4 & $0.96 \mathrm{~s}$ & 33.4 \\
\hline 30 & $0.87 \mathrm{~s}$ & 24.1 & $0.88 \mathrm{~s}$ & 24.1 & $0.87 \mathrm{~s}$ & 24.1 \\
\hline \multirow[t]{2}{*}{ Ac } & & & & & - & 170.7 \\
\hline & & & & & $2.00 \mathrm{~s}$ & 21.5 \\
\hline $\mathrm{C}=\mathrm{O}$ & & & & 156.2 & & \\
\hline $\mathrm{OH}$ & $4.32 \mathrm{~d}(5.2)$ & & & & & \\
\hline $\mathrm{NH}$ & & & $5.55 \mathrm{~d}(3.5)$ & & & \\
\hline $\mathrm{COOH}$ & & & $12.19 \mathrm{~s}$ & & & \\
\hline
\end{tabular}


Table 2: ${ }^{1} \mathrm{H}$ RMN (600 MHz) and ${ }^{13} \mathrm{C}$ NMR (150 MHz) data of compounds (2-4) in DMSO- $d_{6}$

\begin{tabular}{|c|c|c|c|c|c|c|}
\hline $\mathrm{N}^{\circ}$ & 2 & & 3 & & 4 & \\
\hline & $\delta \mathrm{H}, \mathrm{m}(\mathrm{J} \mathrm{Hz})$ & $\delta \mathrm{C}$ & $\delta_{\mathrm{H}}, \mathrm{m}(\mathrm{J} \mathrm{Hz})$ & $\delta \mathrm{C}$ & $\delta \mathrm{H}, \mathrm{m}(\mathrm{J} \mathrm{Hz})$ & $\delta \mathrm{C}$ \\
\hline $1 \alpha$ & $1.45 \operatorname{td}(13.2,3.3)$ & 37.0 & $1.56 \mathrm{~m}$ & 38.5 & $1.61 \mathrm{~m}$ & 38.3 \\
\hline$\beta$ & $1.04 \mathrm{dd}(12.5,3.8)$ & & $0.86 \mathrm{dd}(12.9,3.8)$ & & $0.99 \mathrm{dd}(12.9,3.8)$ & \\
\hline $2 \alpha$ & $1.52 \mathrm{~m}$ & 23.5 & $1.49 \mathrm{~m}$ & 27.4 & $1.58 \mathrm{~m}$ & 23.7 \\
\hline$\beta$ & $1.57 \mathrm{~m}$ & & $1.53 \mathrm{~m}$ & & $1.63 \mathrm{~m}$ & \\
\hline 3 & $4.38 \mathrm{dd}(11.6,4.7)$ & 80.2 & $3.00 \mathrm{dt}(10.6,5.4)$ & 77.1 & $4.43 \mathrm{dd}(11.7,4.7)$ & 80.0 \\
\hline 4 & - & 37.7 & - & 38.9 & - & 37.9 \\
\hline 5 & $0.91 \mathrm{~m}$ & 54.9 & $0.82 \mathrm{~d}(11.6)$ & 55.4 & $1.06 \mathrm{dd}(11.6,3.5)$ & 54.7 \\
\hline $6 \alpha$ & $1.51 \mathrm{~m}$ & 18.6 & $1.58 \mathrm{~m}$ & 19.9 & $1.57 \mathrm{~m}$ & 19.4 \\
\hline$\beta$ & $1.41 \operatorname{td}(12.9,3.4)$ & & $1.58 \mathrm{~m}$ & & $1.57 \mathrm{~m}$ & \\
\hline $7 \alpha$ & $1.96 \mathrm{dt}(13.1,3.1)$ & 40.9 . & $1.34 \mathrm{~m}$ & 36.4 & $1.41 \operatorname{td}(12.1,4.5)$ & 37.2 \\
\hline$\beta$ & $1.18 \operatorname{td}(13.2,3.3)$ & & $1.57 \mathrm{~m}$ & & $1.64 \mathrm{~m}$ & \\
\hline 8 & - & 39.3 & - & 43.5 & - & 43.3 \\
\hline 9 & $1.74 \mathrm{dd}(10.1,9.8)$ & 50.2 & $1.59 \mathrm{~m}$ & 51.8 & $1.80 \mathrm{dd}(13.9,1.9)$ & 48.8 \\
\hline 10 & - & 37.6 & - & 37.5 & - & 37.7 \\
\hline $11 \alpha$ & $2.07 \mathrm{~m}$ & 30.9 & $2.20 \mathrm{~d}(14.7)$ & 27.4 & $1.91 \mathrm{dd}(16.2,13.9)$ & 19.9 \\
\hline$\beta$ & $1.83 \mathrm{dt}(14.0,9.6)$ & & $2.23 \mathrm{~d}(14.7)$ & & $2.85 \mathrm{dd}(16.2,1.9)$ & \\
\hline $12 \beta$ & $4.65 \mathrm{dd}(10.2,8.5)$ & 71.1 & - & 162.6 & - & 165.5 \\
\hline 13 & - & 43.4 & - & 47.8 & - & 46.3 \\
\hline 14 & - & 157.3 & - & 91.1 & - & 90.6 \\
\hline $15 \alpha$ & $5.68 \mathrm{dd}(8.2,3.3)$ & 121.2 & $1.90 \mathrm{~m}$ & 20.9 & $1.99 \operatorname{td}(14.5,2.9)$ & 23.1 \\
\hline$\beta$ & & & $1.73 \operatorname{td}(14.6,6.3)$ & & $1.67 \mathrm{~m}$ & \\
\hline $16 \alpha$ & $2.08 \mathrm{~m}$ & 29.3 & $1.11 \mathrm{~m}$ & 20.3 & $1.12 \mathrm{~m}$ & 21.0 \\
\hline$\beta$ & $1.99 \mathrm{dd}(13.1,3.1)$ & & $2.31 \mathrm{td}(12.6,5.4)$ & & 2.28 ddd $(13.4,10.5,6.4)$ & \\
\hline 17 & - & 50.4 & - & 39.2 & - & 39.2 \\
\hline $18 \beta$ & $2.62 \mathrm{dd}(13.4,4.6)$ & 40.0 & $2.07 \mathrm{dm}(12.1)$ & 41.3 & $2.45 \mathrm{dd}(13.0,4.0)$ & 41.5 \\
\hline $19 \alpha$ & $1.53 \mathrm{dd}(13.4,3.6)$ & 37.1 & $1.90 \mathrm{t}(12.1)$ & 35.4 & $1.51 \mathrm{t}(13.0)$ & 36.5 \\
\hline$\beta$ & $1.18 \mathrm{t}(13.4)$ & & $1.38 \mathrm{~d}(12.1)$ & & $1.32 \mathrm{dd}(13.0,4.0)$ & \\
\hline 20 & - & 30.9 & - & 31.4 & - & 30.9 \\
\hline $21 \alpha$ & $1.10 \mathrm{~m}$ & 33.7 & $1.20 \mathrm{~m}$ & 33.4 & $1.17 \mathrm{~m}$ & 33.4 \\
\hline$\beta$ & $1.08 \mathrm{~m}$ & & $1.17 \mathrm{~m}$ & & $1.21 \mathrm{td}(12.9,3.9)$ & \\
\hline $22 \alpha$ & 1.59 ddd $(12.6,8.1,4.1)$ & 31.5 & $1.29 \mathrm{dt}(14.4,3.3)$ & 27.6 & $1.27 \mathrm{dt}(14.3,3.6)$ & 27.3 \\
\hline$\beta$ & $1.42 \mathrm{~m}$ & & $1.74 \operatorname{td}(13.9,5.4)$ & & $1.82 \operatorname{td}(13.9,5.8)$ & \\
\hline 23 & $0.79 \mathrm{~s}$ & 28.0 & $0.85 \mathrm{~s}$ & 28.2 & $0.79 \mathrm{~s}$ & 27.8 \\
\hline 24 & $0.81 \mathrm{~s}$ & 16.8 & $0.69 \mathrm{~s}$ & 15.8 & $0.83 \mathrm{~s}$ & 16.6 \\
\hline 25 & $0.89 \mathrm{~s}$ & 15.7 & $0.85 \mathrm{~s}$ & 17.7 & $0.92 \mathrm{~s}$ & 17.4 \\
\hline 26 & $0.87 \mathrm{~s}$ & 27.1 & $1.09 \mathrm{~s}$ & 19.1 & $1.02 \mathrm{~s}$ & 18.5 \\
\hline 27 & $1.02 \mathrm{~s}$ & 19.1 & $1.32 \mathrm{~s}$ & 18.0 & $1.37 \mathrm{~s}$ & 23.6 \\
\hline 28 & - & 179.1 & - & 177.9 & - & 177.8 \\
\hline 29 & $0.91 \mathrm{~s}$ & 32.3 & $0.94 \mathrm{~s}$ & 33.8 & $0.96 \mathrm{~s}$ & 33.6 \\
\hline 30 & $0.91 \mathrm{~s}$ & 26.6 & $0.78 \mathrm{~s}$ & 23.8 & $0.83 \mathrm{~s}$ & 24.3 \\
\hline $\mathrm{OH}$ & & & $4.32 \mathrm{~d}(5.4)$ & & & \\
\hline $\mathrm{NOH}$ & & & & & $10.51 \mathrm{~s}$ & \\
\hline \multirow[t]{2}{*}{ Ac } & - & 170.6 & & & - & 170.6 \\
\hline & $2.00 \mathrm{~s}$ & 21.5 & & & $2.01 \mathrm{~s}$ & 21.5 \\
\hline
\end{tabular}

